\title{
Bacterial Leaf Spot Diseases of Leafy Crucifers in Oklahoma Caused by Pathovars of Xanthomonas campestris
}

\author{
Youfu Zhao, John P. Damicone, Department of Entomology and Plant Pathology; David H. Demezas, Department \\ of Microbiology and Molecular Genetics; and Carol L. Bender, Department of Entomology and Plant Pathology, \\ Oklahoma State University, Stillwater 74078-3033
}

\begin{abstract}
Zhao, Y., Damicone, J. P., Demezas, D. H., and Bender, C. L. 2000. Bacterial leaf spot diseases of leafy crucifers in Oklahoma caused by pathovars of Xanthomonas campestris. Plant Dis. 84:1008-1014.

Fields of kale, spinach mustard, and turnip were severely damaged by bacterial leaf spots during 1994 to 1996. Symptoms included circular to angular necrotic lesions with yellow halos and water-soaking on the abaxial leaf surface. Yellow, mucoid strains isolated from leaf spots were identified as Xanthomonas campestris using Biolog. Four strains caused black lesions on stems of cabbage seedlings in an excised cotyledon assay, leaf spots and sunken dark lesions on petioles of spray-inoculated crucifers, and leaf spots on spray-inoculated tomato. These strains were classified as X. campestris pv. armoraciae. Most other strains from leafy crucifers and all strains from a cabbage field caused black rot in the cotyledon assay and in spray-inoculations. Many of these strains also caused leaf spots on collard and kale but not stem and petiole lesions. The strains causing black rot were classified as X. campestris pv. campestris. Cluster analysis of Biolog profiles yielded a small group that contained local strains of both pathovars, and a large group comprised of reference and local strains of each pathovar, and some local, nonpathogenic strains. Five fingerprint groups were identified by rep-polymerase chain reaction using the BOXA1R primer. Local and reference strains of each pathovar occurred in two of the groups. Two pathovars of $X$. campestris are involved in the leaf spot diseases. Both pathovars were recovered within several fields, and also were recovered along with Pseudomonas syringae pv. maculicola. This is the first report of Xanthomonas leaf spot caused by X. campestris pv. armoraciae in Oklahoma.
\end{abstract}

The leafy crucifers collards (Brassica oleracea var. viridis L.), kale (B. oleracea var. sabellica L.), mustard (B. juncea L. var. crispifolia Bailey), spinach mustard (B. rapa L. var. perviridis Bailey), and turnip (B. rapa var. utilis (D.C.) Metzg.) are important minor crops that are grown for processing in Oklahoma. About 600 ha are grown each year during both spring and fall cropping seasons (2). The crops are directseeded and harvested in bulk with nonselective cutters up to three times per production season. Because of the nonselective harvesting procedure, leaf blemishing from disease can reduce product grade and value. Severely diseased fields may be discounted or even rejected by processors, resulting in total economic loss.

During 1994 to 1996, fields of kale, spinach mustard, and turnip in eastern Oklahoma were severely damaged by bacterial leaf spots. Symptoms included circular to angular, interveinal, necrotic lesions with yellow halos. Lesions ranged in

Corresponding author: J. P. Damicone

E-mail:.jpd3898@okstate.edu

Accepted for publication 1 June 2000 .

Publication no. D-2000-0713-01R

(C) 2000 The American Phytopathological Society size from $2 \mathrm{~mm}$ to over $1 \mathrm{~cm}$ in size. Chlorotic haloes surrounding isolated spots were narrow ( 1 to $2 \mathrm{~mm}$ ). However chlorosis was general on areas of leaves where small lesions were numerous. Lesion margins were usually water-soaked on the abaxial surface. Spots coalesced and resulted in extensive leaf necrosis and death. Up to $70 \%$ of leaves were affected. Where disease incidence was lower, affected leaves were often of a similar age. In some fields, dark elliptical lesions, 2 to $4 \mathrm{~mm}$ in length, were numerous on petioles and large, abaxial leaf veins. Both Pseudomonas syringae and Xanthomonas campestris were isolated from diseased leaves. Bacterial leaf spot, caused by $P$. syringae pv. maculicola, has since been identified as an important component of the leaf spot

Several pathovars of $X$. campestris, including pv. campestris, the cause of black rot (35); pv. armoraciae, the cause of Xanthomonas leaf spot of horseradish (Armoracia rusticana Gaertn. et al. [16]); and pv. raphani, the cause of bacterial leaf spot of radish (Raphanus sativus var. sativus L.) and turnip (34); are known to cause leaf spots on crucifers (4). These pathogens have been reported to cause severe losses on leafy crucifers $(1,2,28,35)$.

Black rot has been reported in all countries where crucifers are grown and rediseases $(38,39)$. mains a persistent problem $(18,35)$. Typical symptoms include $\mathrm{V}$-shaped lesions on leaf margins and blackened veins associated with systemic movement of the pathogen (1,35). As a vascular pathogen, $X$. campestris pv. campestris is normally not associated with leaf spot symptoms. However, it has been reported to cause atypical symptoms that mimic those of other bacterial pathogens $(7,17,19,36)$. These include leaf blights $(1,6,36)$, water-soaked lesions, and soft rot (26). In Australia, a bacterial leaf spot disease of cabbage $(B$. oleracea var. capitata L.), cauliflower (B. oleracea var. botrytis L.), and broccoli (B. oleracea L. var. italica Plenck.) was reported to have symptoms differing from black rot (17). The pathogen was indistinguishable from $X$. campestris pv. campestris both morphologically and physiologically, and could not be differentiated on the basis of symptoms. $X$. campestris pv. campestris is also known to infect several cruciferous weeds $(4,28,29,31)$.

Xanthomonas leaf spot of crucifers, caused by $X$. campestris pv. armoraciae or pv. raphani was first reported on horseradish in 1929 and on radish and turnip in 1930 (16,34). The disease has been reported in many countries including the United States, Japan (30), Brazil, China (37), Turkey, and India (4). Typical symptoms include small, water-soaked, olive green lesions with a yellow halo $(3,16,28)$. Black, sunken, and elongated lesions on stems and petioles may rapidly kill young plants (4). The symptoms of Xanthomonas leaf spot closely resemble those of bacterial leaf spot of cauliflower caused by $P$. syringae pv. maculicola $(23,28)$. A different pathotype of $X$. campestris pv. armoraciae, recently reported in Ohio, differed in host range from previously reported strains (23). Additional hosts for $X$. campestris pv. armoraciae include tomato (Lycopersicon esculentum Mill.), pepper (Capsicum annum L.), and tobacco (Nicotiana tabacum L. [3,4,15, $30,37])$.

In a recent national assessment of the importance of diseases of leafy green vegetables and their management, bacterial leaf spots were not recognized (2). The objective of this study was to identify and characterize the strains of $X$. campestris isolated from leaf spots of leafy crucifers in Oklahoma. A preliminary report of this work has been published (38). 


\section{MATERIALS AND METHODS}

Bacterial strains. Leaves with leaf spot symptoms were collected from 10 fields cropped to either kale, spinach mustard, or turnip in eastern Oklahoma from 1994 to 1996. Sections of leaves with lesions were excised, surface sterilized in $0.25 \%$ aqueous sodium hypochlorite for $30 \mathrm{sec}$, and rinsed in sterile tap water. Leaf sections were macerated in sterile tap water and the extract was inoculated to nutrient agar (NA) and several semi-selective media (5), including Fieldhouse-Sasser medium (FS [8]), basal starch cycloheximide antibiotic agar (BSCAA [21]) and nutrient starch cycloheximide antibiotic agar (NSCAA [21]). Plates were incubated at $28^{\circ} \mathrm{C}$ and examined after 3 to 5 days for bacterial growth and cleared zones indicative of starch hydrolysis. Single, yellow (NA, NSCAA and BSCAA) or bluish white (FS) bacterial colonies that utilized the starch on semi-selective media were selected and purified on NA for further identification and characterization. Twenty-nine strains of Xanthomonas spp. from leafy crucifers were recovered for characterization (Table 1). A cabbage field in western Oklahoma with severe black rot also was sampled in
1997. Isolations were made from V-shaped lesions on leaf margins and from leaf spots using the methods described above. Sixteen strains of Xanthomonas spp. were recovered from the cabbage field and also characterized (Table 1). Gram stains were performed on all local strains. Thirteen strains of $X$. campestris pv. campestris or pv. armoraciae were obtained from various sources and used as reference strains (Table 1). All strains used in this study were stored in $15 \%$ glycerol at $-70^{\circ} \mathrm{C}$ and were routinely cultured on NA or LuriaBertani medium (LB [24]) at $28^{\circ} \mathrm{C}$.

Carbon source oxidation. Strains were assayed for oxidation of the 95 carbon sources available on the GN MicroPlates (Biolog Inc., Hayward, CA). Bacteria were grown on trypticase soy agar (TSA; Bacto Tryptic Soy Broth, 15 g/liter agar; Difco Laboratories, Detroit, MI) for $24 \mathrm{~h}$ at $28^{\circ} \mathrm{C}$. Cells were transferred from the TSA plates to $30 \mathrm{ml}$ test tubes containing $20 \mathrm{ml}$ of sterile saline $(0.85 \% \mathrm{NaCl})$. The optical density (OD) of the suspension was adjusted as recommended by the manufacturer. Microplates were inoculated with $150 \mu \mathrm{l}$ of suspension per well and incubated at $28^{\circ} \mathrm{C}$. The absorbency of the wells at $590 \mathrm{~nm}$ was determined at both 24 and $48 \mathrm{~h}$ using a plate reader (Molecular Devices Corp., Sunnyvale, CA). MicroLog 2 (version 3.5, Biolog Inc.) and the GN database (version 3.5) were used for strain identification. Similarity coefficients were determined using NTSYS-PC (22). Cluster analysis was performed using the unweighted pair-group method, and dendrograms were generated using the SAHN subroutine of NTSYS-PC. The repeatability of the assay was confirmed by running a set of 18 arbitrarily selected strains twice. The assay was then performed on all 45 local strains and nine of 13 reference strains.

Pathogenicity. To assess the pathogenicity and host range of bacterial strains, inoculum was prepared by growing strains on NA at $28^{\circ} \mathrm{C}$ for $48 \mathrm{~h}$. Cells were suspended in sterile tap water and adjusted to a concentration of approximately $10^{7}$ $\mathrm{CFU} / \mathrm{ml}$ as determined by OD readings and bacterial counts by dilution plating.

Various crops were produced from seed in 12.7-cm-diameter pots containing soilless media (Metro-Mix 200, Scotts-Sierra Horticultural Products Co., Marysville, $\mathrm{OH})$. Plants were maintained in a green-

Table 1. Strains of Xanthomonas campestris used in this study

\begin{tabular}{|c|c|c|c|c|}
\hline Strain & Field & Host & Location & Source $^{\mathrm{w}}$ (reference) \\
\hline \multicolumn{5}{|l|}{ pv. campestris } \\
\hline $\mathrm{BR} 1, \mathrm{BR} 4, \mathrm{BR} 5, \mathrm{BR} 6, \mathrm{BR} 7, \mathrm{BR} 9, \mathrm{BR} 13$ & 1-1994 & Turnip & Oklahoma & This study \\
\hline BR15, BR23 & 2-1995 & Spinach mustard ${ }^{\mathrm{x}}$ & Oklahoma & This study \\
\hline BR24 & 3-1995 & Turnip & Oklahoma & This study \\
\hline BR17, BR27 & 4-1995 & Turnip & Oklahoma & This study \\
\hline BR18 & $5-1995$ & Spinach mustard ${ }^{y}$ & Oklahoma & This study \\
\hline BR19 & 6-1995 & Spinach mustard ${ }^{y}$ & Oklahoma & This study \\
\hline BR20, BR26 & 7-1995 & Kale & Oklahoma & This study \\
\hline $\mathrm{BR} 21, \mathrm{BR} 22, \mathrm{BR} 28$ & $8-1995$ & Kale & Oklahoma & This study \\
\hline BR29, BR30, BR31 & 9-1996 & Spinach mustard ${ }^{\mathrm{x}}$ & Oklahoma & This study \\
\hline BR33, BR34, BR35 & $10-1996$ & Turnip & Oklahoma & This study \\
\hline BR37, BR39, BR40, BR43, BR46, BR47, BR48 & 1997 & Cabbage (black rot) & Oklahoma & This study \\
\hline BR41, BR42, BR44, BR45, BR49, BR50, BR51, BR52, BR53 & 1997 & Cabbage (leaf spot) & Oklahoma & This study \\
\hline Xcc528 & & Brussels sprouts & United Kingdom & ATCC $33913(1,6)$ \\
\hline PHW-117 & & Cabbage & Wisconsin & D. Cuppels (1) \\
\hline Xcc1205 & & Cabbage & Wisconsin & P. Williams \\
\hline 3150 & & $?$ & Florida & R. Stall \\
\hline 16936 & & Cabbage ("A") & Florida & R. Stall \\
\hline 16937 & & Cabbage ("B") & Florida & R. Stall \\
\hline JT1 & & Cabbage & Michigan & D. Cuppels (13) \\
\hline JT4 & & Arabidopsis & Michigan & D. Cuppels (13) \\
\hline \multicolumn{5}{|l|}{ pv. armoraciae } \\
\hline BR11 & $1-1994$ & Turnip & Oklahoma & This study \\
\hline BR16 & $3-1995$ & Turnip & Oklahoma & This study \\
\hline BR25 & $5-1995$ & Spinach mustard ${ }^{y}$ & Oklahoma & This study \\
\hline BR32 & $9-1996$ & Spinach mustard ${ }^{x}$ & Oklahoma & This study \\
\hline XLS6 & & Cabbage & N. Carolina & L. Black (1) \\
\hline 756 & & Cabbage seed & E. Asia & D. Gabriel (1) \\
\hline $3145^{z}$ & & ? & Florida & R. Stall \\
\hline 3152 & & ? & Florida & R. Stall \\
\hline $69-2^{z}$ & & Radish & Florida & D. Cuppels \\
\hline
\end{tabular}

${ }^{\mathrm{w}}$ Local strains from kale, spinach mustard, and turnip were isolated from leaf spots on leaves collected in 10 fields in eastern Oklahoma. Local strains from cabbage were isolated from either V-shaped lesions (black rot) or leaf spots collected from a cabbage field in western Oklahoma. All local strains were identified based on results in this paper. Reference strains were received from: L. L. Black, Department of Plant Pathology and Crop Physiology, Louisiana State University, Baton Rouge 70803; D. Cuppels, Agriculture and Agri-Food Canada, London, Ontario N5V 4T3; D. Gabriel and R. Stall, Department of Plant Pathology, University of Florida, Gainesville 32611; P. Williams, Department of Plant Pathology, University of Wisconsin, Madison 53706.

${ }^{x}$ Cultivar Savannah used by processor as mustard greens.

y Cultivar Tendergreen used by processor as turnip greens.

${ }^{\mathrm{z}}$ Strains were received as pv. raphani, which was considered synonymous with pv. armoraciae in this study (1). 
house at 20 to $25^{\circ} \mathrm{C}$, thinned to one per pot at the cotyledon stage, and fertilized every 2 weeks with soluble 20-20-20 (N-P-K) fertilizer. Plants were grown for 3 weeks until they had three to four true leaves at the time of inoculation except for cabbage and tomato, which were 6 weeks old. Horseradish was produced vegetatively from retail roots that were sectioned and planted in pots. Horseradish was maintained as described above for 8 weeks prior to inoculation.

Plants were incubated in polyethylene humidity chambers within the greenhouse at $100 \%$ relative humidity for 24 to $48 \mathrm{~h}$ before and after inoculation. Bacterial suspensions were applied with an airbrush at $172 \mathrm{kPa}$ until leaves were uniformly wet. Collards (cv. Vates), kale (cv. Dwarf Blue Curled Scotch), mustard (cv. Southern Giant Curled), spinach mustard (cv. Tendergreen), turnip (cv. Hybrid Alltop), radish (cv. Scarlett Knight), and tomato (cv. Summer Flavor 3000) were inoculated with each local strain and nine of the 13 reference strains. Horseradish was inoculated with selected strains. After incubation, plants were removed from the humidity chambers and maintained in the greenhouse until symptoms were assessed, 7 to 14 days after inoculation. The presence or absence of leaf spot and black rot symptoms were recorded for each crop. Symptoms of leaf spot included interveinal necrotic lesions surrounded by chlorotic halos. Symptoms of black rot included Vshaped lesions along leaf margins bordered by chlorosis and darkening of leaf veins. Three replicate plants of each crop were inoculated with each strain and the entire set of inoculations was repeated. Water was used as a control for each set of inoculations.

An excised-cotyledon assay on cabbage seedlings was performed on all strains to differentiate $X$. campestris pv. campestris and pv. armoraciae as described by Alvarez et al. (1). Cabbage (cv. Early Jersey) was grown from seed in the greenhouse for 8 to 10 days until the first true leaf was visible and cotyledons were fully expanded. One cotyledon per seedling was excised close to the stem and the wound surface was inoculated with a mass of bacteria from a single colony grown on NA for $24 \mathrm{~h}$ at $28^{\circ} \mathrm{C}$. Three replicate plants were inoculated with each strain, and the entire set of inoculations was repeated. After inoculation, plants were maintained in the greenhouse until symptoms were assessed at 4, 7, and 14 days after inoculation. Strains that caused black stem lesions by 4 to 7 days after inoculation were classified as X. campestris pv. armoraciae (1). Strains that did not cause stem lesions at 4 to 7 days after inoculation and induced the systemic symptoms typical of black rot, were classified as $X$. campestris pv. campestris (1). The severity of black rot for strains of $X$. campestris pv. campestris was assessed at 14 days after inoculation, using a disease index (DI) of 0 to 9 , in which $0=$ healthy and $9=$ dead (1). A mean DI was calculated for each strain and strains with a DI of 0 to 1 were considered avirulent, 1.1 to 3 were weakly virulent, 3.1 to 6 were moderately virulent, 6.1 to 8 were virulent, and 8.1 to 9 were highly virulent (1).

Genetic fingerprinting. To assess the genetic diversity of strains of $X$. campestris, repetitive sequence-based polymerase chain reaction fingerprinting (rep-PCR) was performed on all strains. The BOX primer BOXA1R [5'-CTACGGCAAGGC GACGCTGACG] was synthesized by the Oklahoma State University Recombinant DNA/Protein Resource Facility. Rep-PCR was carried out as previously described (12). Bacteria were initially grown on NA at $28^{\circ} \mathrm{C}$ for $24 \mathrm{~h}$, and then transferred to 5 $\mathrm{ml}$ of LB broth (24) and incubated at $28^{\circ} \mathrm{C}$, $280 \mathrm{rpm}$, for $18 \mathrm{~h}$. Cultures $(1 \mathrm{ml})$ were harvested by centrifugation, and pellets were washed in $0.5 \mathrm{ml}$ of $0.5 \mathrm{M} \mathrm{NaCl}$ and resuspended in $50 \mu \mathrm{l}$ sterile distilled water to a final concentration of $10^{10} \mathrm{CFU} / \mathrm{ml}$. Repetitive DNA elements were amplified in a $25 \mu \mathrm{l}$ reaction volume. Each reaction consisted of $1 \times$ Gitschier buffer $(16.6 \mathrm{mM}$ $\left[\mathrm{NH}_{4}\right]_{2} \mathrm{SO}_{4} ; 67 \mathrm{mM} \mathrm{HCl}, \mathrm{pH} 8.8 ; 6.7 \mathrm{mM}$ $\mathrm{MgCl}_{2} ; 6.7 \mathrm{~m} M$ EDTA; $30 \mathrm{mM}$ ß-mercaptoethanol), $4 \mu \mathrm{g}$ bovine serum albumin, $10 \%$ dimethyl sulfoxide (vol/vol) (Fluka Chemical Corp., Ronkonkoma, NY), 50 pmoles of the primer, $1.25 \mathrm{~m} M$ of each dNTP (Boehringer Mannheim, Indianapolis, IN), 2 units of Taq polymerase (Promega, Madison, WI), and $1 \mu \mathrm{l}$ of the bacterial suspension. Each reaction set included a negative control containing water only. Reaction mixtures were overlaid with $25 \mu \mathrm{l}$ of sterile mineral oil. The PCR was performed in a thermal cycler (Model 480, Perkin-Elmer Cetus, Norwalk, CT) under the following conditions: 1 cycle at $95^{\circ} \mathrm{C}$ for $6 \mathrm{~min}, 30$ cycles at $94^{\circ} \mathrm{C}$ for $1 \mathrm{~min}, 50^{\circ} \mathrm{C}$ for $1 \mathrm{~min}$, and $65^{\circ} \mathrm{C}$ for 8 min, followed by $65^{\circ} \mathrm{C}$ for $16 \mathrm{~min}$. An $8-\mu \mathrm{l}$ aliquot of the PCR reaction was analyzed by gel electrophoresis on a $1.5 \%$ agarose gel at $70 \mathrm{~V}$ for $5 \mathrm{~h}$ in $1 \times$ TBE buffer $(\mathrm{pH}$ 8.3 ). Gels were stained with ethidium bromide and differences in DNA fingerprint patterns were assessed visually. The assay was performed twice for each strain.

\section{RESULTS}

Bacterial strains. Of the 45 local strains of Xanthomonas spp., including 29 strains from leafy crucifers and 16 strains from cabbage, all were gram-negative and yellow-pigmented on NA, and utilized starch on semi-selective media. On FS medium, the colonies were bluish-white, translucent, raised, and mucoid. On NSCAA and BSCAA, the colonies were greenish-yellow, translucent, and mucoid. Based on these characteristics all of the local strains were identified as $X$. campestris (25). $X$. campestris was recovered from each of the
10 fields of leafy crucifers with leaf spot symptoms.

Carbon source oxidation. For Xanthomonas spp., an incubation time of $48 \mathrm{~h}$ was necessary for full color development on the Biolog GN MicroPlates, an observation also noted elsewhere (32). All local strains and reference strains were identified as $X$. campestris. Seventeen strains were further classified as $X$. campestris pv. campestris, with similarity coefficients ranging from 43.2 to $88.2 \%$. The Biolog GN database placed another nine strains close to $X$. campestris pv. campestris, but with lower similarity coefficients (<40\%). Other strains were assigned to other pathovars of $X$. campestris by the database.

Cluster analysis of the carbon source utilization profiles for local strains and for reference strains of $X$. campestris pv. armoraciae and pv. campestris produced two groups, A and B (Fig. 1). The similarity within each group was $80 \%$ or greater. Local strains, identified by pathogenicity as $X$. campestris pv. campestris and pv. armoraciae (see below), were found in both groups, but all reference strains of $X$. campestris pv. campestris and pv. armoraciae were in group B.

Pathogenicity. Among the 45 local strains, only four caused black lesions on stems of cabbage seedlings within 7 days after inoculation using the cotyledon assay (Table 2). There was no further symptom development for these strains. Except for strain 3152, reference strains of $X$. campestris pv. armoraciae produced the same symptoms. The four local strains that caused stem lesions, each recovered from a different field, were designated as $X$. campestris pv. armoraciae. In spray inoculations of various crucifers and tomato, the four strains caused localized leaf spots with chlorotic halos, but no symptoms of systemic infection. The four strains also caused elongated, black, sunken lesions on petioles and stems of collard, kale, turnip, and spinach-mustard when inoculated by spraying. Except for strain 3152, reference strains of $X$. campestris pv. armoraciae produced similar symptoms. All strains of $\mathrm{X}$. campestris pv. armoraciae were very aggressive and caused severe leaf spotting on tomato and all crucifers except horseradish (Table 2). Strains were less aggressive on horseradish, and two local strains were non-pathogenic on this host. The reference strain 16936, received as $X$. campestris "A", was classified here as $X$. campestris pv. armoraciae based on pathogenicity tests.

Among the remaining 25 local strains of $X$. campestris from leafy crucifers, all but eight caused systemic symptoms of black rot, but not stem lesions, in the excised cotyledon assay (Table 2). However, these local strains varied in virulence in the cotyledon assay. Thirteen of the local strains induced severe blight symptoms within 10 days and caused seedling death 
within 14 days. These were ranked as highly virulent to virulent based on the disease index. Four local strains caused black rot symptoms in at least one true leaf within 14 days and were ranked as moderately to weakly virulent. Most of the reference strains of $X$. campestris pv. campestris caused similar symptoms and also varied in virulence (Table 2). The seventeen local strains that produced black rot symptoms, recovered from eight of the ten fields of leafy crucifers sampled, were designated as $X$. campestris pv. campestris. In addition, all sixteen strains from the cabbage field caused black rot and were highly virulent to virulent in the cotyledon assay. Reference strain 3152, received as $X$. campestris pv. armoraciae, was reclassified as $X$. campestris pv. campestris based on the cotyledon assay. The other eight local strains and reference strain 16937 were avirulent in the cotyledon assay.

When inoculated by spraying, local and reference strains of $X$. campestris pv. campestris that were weakly to highly virulent in the cotyledon assay, generally caused black rot on all crucifers except horseradish and were nonpathogenic on tomato (Table 2). Several strains were nonpathogenic on mustard, and a few were nonpathogenic on radish and collards. Generally, symptoms were most severe on collards, kale, turnip, and spinach-mustard. Most local strains of $X$. campestris pv. campestris, including all strains from the cabbage field, also caused leaf spots on collard and kale. The symptoms were very similar to those caused by strains of $X$. campestris pv. armoraciae. However, none of the strains of $X$. campestris pv. campestris caused leaf spots on the other crucifers or caused lesions on stems and petioles of any of the crucifers. Except for strain BR1, which caused mild black rot symptoms on turnip and radish, strains that were avirulent in the cotyledon assay also did not cause symptoms on any of the crops inoculated by spraying.

Genetic fingerprinting. In the fingerprints generated for strains of $X$. campestris, more than 20 DNA fragments, ranging in size from approximately 0.3 to $4.0 \mathrm{~kb}$, were amplified with the BOXA1R primer. Five distinct groups of strains identified by these fingerprint patterns were arbitrarily designated as A-E. Most strains (35 of 58) were assigned to group A (Table 2), which included weakly to highly virulent local strains of $X$. campestris pv. campestris (Fig. 2, lanes 4 to 6), local strains of nonpathogenic $X$. campestris (lane 7), local strains of $X$. campestris pv. armoraciae (lane 8), and reference strains of both pathovars (lanes 1 to 3, 9). All 16 local strains of $X$. campestris pv. campestris isolated from the cabbage field belonged to this group (Table 2). Three nonpathogenic strains of $X$. campestris had fingerprints identical to those of highly virulent strains of $X$. campestris pv. campestris in group A.
Group B (Fig. 2, lanes 10 to 11) included ten local and reference strains of $X$. campestris pv. campestris that were moderately to highly virulent (Table 2). Group C (Fig. 2 , lanes 12 to 14) consisted of five local or reference strains of $X$. campestris pv. armoraciae and four nonpathogenic strains of $X$. campestris (Table 2). Group D included only one reference strain of $X$. campestris pv. armoraciae (Fig. 2, lane 15). Three local strains of nonpathogenic $X$. campestris and a highly virulent reference strain of $X$. campestris pv. campestris formed group E (Fig. 2, lanes 16 to 18). Group E was variable, but differed from other groups by the presence of a $0.3-\mathrm{kb}$ band (Fig. 2, shown with an arrow).

\section{DISCUSSION}

$X$. campestris pv. armoraciae and pv. campestris were identified as causal agents of leaf spot diseases of leafy crucifers in Oklahoma. Pathogenic strains of X. campestris were recovered from eight of the ten fields sampled. $X$. campestris pv. ar- moraciae, the cause of Xanthomonas leaf spot, was recovered from four fields. $X$. campestris pv. armoraciae was an aggressive pathogen that attacked leaves, stems, and petioles of collards, kale, mustard, spinach mustard, and turnip. However, it caused only a few small leaf spots on horseradish, the crop from which the pathovar was named and first described. This is the first report of Xanthomonas leaf spot of crucifers in Oklahoma. X. campestris pv. campestris, the cause of black rot, was recovered from leaf spots in eight fields. Although black rot was previously reported in Oklahoma on cabbage and broccoli (20), the pathogen was not associated with leaf spot symptoms. In this study, $X$. campestris pv. campestris caused leaf spot, but not stem and petiole lesions, on collards and kale. However, local and reference strains of $X$. campestris pv. campestris were not shown to cause leaf spot on spinach mustard or turnip, despite the recovery of several strains from leaf spots on these crops.

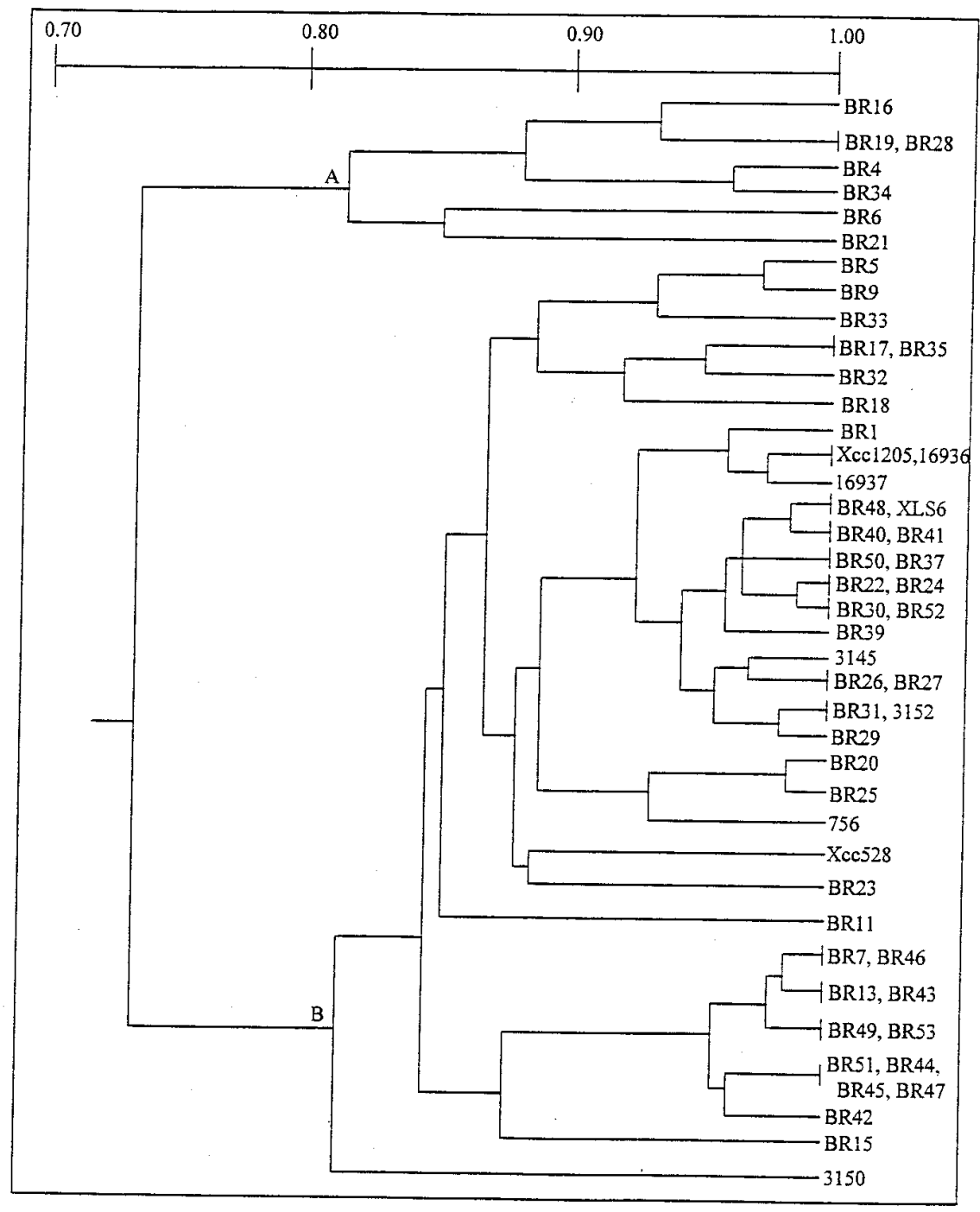

Fig. 1. Dendrogram showing the relationships among strains of Xanthomonas campestris for carbon source oxidation as determined with GN MicroPlates (Biolog Inc., Hayward, CA). (A) and (B) represent groups with $>80 \%$ similarity. 
$X$. campestris pv. campestris is typically a vascular pathogen that moves systemically in the plant and normally invades the host through wounds and hydathodes $(26,28)$. Infections caused by $X$. campestris pv. armoraciae usually originate at stomatal openings (28). Since $X$. campestris pv. campestris has a wide host range and host susceptibility may differ $(4,28)$, infection directly through stomata could occur in highly susceptible crops including collard, cabbage, and kale (28). Moffet et al. (17) reported a similar bacterial leaf spot disease caused by $X$. campestris pv. campestris on cabbage, cauliflower, and broccoli in Australia. It also was reported that virulent black rot strains caused pinpoint sized, water-soaking symptoms on seedlings prior to the development of black rot (1). Conversely, no variation in symptom expression has been reported for strains of $X$. campestris pv. armoraciae (1). None of the strains of $X$. campestris pv. campestris from the cabbage field in western Oklahoma, including the eight that were iso- lated from leaf spots, caused leaf spot on any crop. This suggests that environmental conditions may play a role in non-vascular infection and/or expression of leaf spot symptoms by $X$. campestris pv. campestris. Abrasion from wind-blown sand, a common occurrence in Oklahoma, may also be involved in non-systemic infection.

The two pathovars of $X$. campestris were both isolated from leaf spots in four fields. Along with bacterial leaf spot caused by $P$. syringae pv. maculicola, which also was recovered from leaf spots in diseased fields $(38,39)$, the pathovars of $X$. campestris formed a complex of leaf spot diseases. Gitaitis et al. (9) reported that mixed infections of $X$. campestris pv. vesicatoria, $P$. syringae $\mathrm{pv}$. syringae, $P$. syringae pv. tomato, and unknown pectolytic xanthomonads occurred on both tomato and pepper transplants. Furthermore, Shen and Chen (27) isolated $X$. campestris pv. campestris together with pathogenic Pseudomonas spp. from diseased cabbage and cauliflower leaves in China.
The genus Xanthomonas was recently reclassified into 20 new species based on genomic relationships revealed by DNADNA homology $(32,33)$. The type species, $X$. campestris, was amended to include only seven pathovars from crucifers including pvs. campestris, armoraciae, and raphani (32). Pathovars within the species could not be differentiated by fatty acid profiling, protein profiling, DNA-DNA hybridization, serology, or restriction fragment length polymorphisms (RFLP $[1,15,32,33])$

In this study, profiles for carbon source oxidation with the Biolog GN MicroPlates were not definitive for identifying the two pathovars of $X$. campestris. The Biolog GN database correctly classified 15 strains as $X$. campestris pv. campestris, but based on pathogenicity, incorrectly identified two strains of $X$. campestris pv. armoraciae (BR32 and XLS6) as X. campestris pv. campestris. Other strains were also assigned to incorrect pathovars. Likewise, grouping the strains for similarity in car-

Table 2. Pathogenicity ${ }^{\mathrm{u}}$, host range, and genetic fingerprint groups using repetitive sequence-based polymerase chain reaction fingerprinting (rep-PCR) for strains of Xanthomonas campestris from crucifers

\begin{tabular}{|c|c|c|c|c|c|c|c|c|c|c|c|}
\hline \multirow[b]{3}{*}{ Strain } & \multirow{2}{*}{\multicolumn{2}{|c|}{ Cotyledon assay $^{v}$}} & \multicolumn{9}{|c|}{ Spray inoculation ${ }^{w}$} \\
\hline & & & \multirow[b]{2}{*}{ Collard } & \multirow[b]{2}{*}{ Kale } & \multirow[b]{2}{*}{ Mustard } & \multirow{2}{*}{$\begin{array}{l}\text { Spinach } \\
\text { mustard }\end{array}$} & \multirow[b]{2}{*}{ Turnip } & \multirow[b]{2}{*}{ Radish } & \multirow{2}{*}{$\begin{array}{l}\text { Horse- } \\
\text { radish }\end{array}$} & \multirow[b]{2}{*}{ Tomato } & \multirow{2}{*}{$\begin{array}{c}\text { rep-PCR } \\
\text { group }^{\mathrm{x}}\end{array}$} \\
\hline & Symptom & Severity & & & & & & & & & \\
\hline \multicolumn{12}{|l|}{ pv. campestris } \\
\hline BR4 & $\mathrm{BR}$ & $\mathrm{HV}$ & BR, LS & $\mathrm{BR}$ & - & $\mathrm{BR}$ & $\mathrm{BR}$ & - & - & - & A \\
\hline BR7, BR24, BR29 & $\mathrm{BR}$ & HV & BR, LS & BR, LS & $\mathrm{BR}$ & $\mathrm{BR}$ & $\mathrm{BR}$ & $\mathrm{BR}$ & - & - & B \\
\hline BR21, BR22 & $\mathrm{BR}$ & $\mathrm{HV}$ & BR, LS & BR, LS & - & $\mathrm{BR}$ & $\mathrm{BR}$ & $\mathrm{BR}$ & - & - & A \\
\hline $\mathrm{BR} 28$ & $\mathrm{BR}$ & HV & BR & $\mathrm{BR}$ & - & $\mathrm{BR}$ & $\mathrm{BR}$ & $\mathrm{BR}$ & - & - & B \\
\hline BR33 & $\mathrm{BR}$ & $\mathrm{HV}$ & BR & $\mathrm{BR}$ & - & $\mathrm{BR}$ & $\mathrm{BR}$ & $\mathrm{BR}$ & - & - & A \\
\hline BR34 & BR & $\mathrm{HV}$ & BR, LS & $\mathrm{BR}$ & - & BR & $\mathrm{BR}$ & BR & - & - & A \\
\hline BR39 - BR53 & $\mathrm{BR}$ & $\mathrm{HV}$ & BR, LS & BR, LS & - & $\mathrm{BR}$ & $\mathrm{BR}$ & $\mathrm{BR}$ & $\ldots$ & - & A \\
\hline Xcc1205 & $\mathrm{BR}$ & $\mathrm{HV}$ & $\mathrm{BR}$ & BR, LS & $\mathrm{BR}$ & $\mathrm{BR}$ & $\mathrm{BR}$ & $\mathrm{BR}$ & $\ldots$ & - & A \\
\hline JT1, PHW-117 & $\mathrm{BR}$ & $\mathrm{HV}$ & $\ldots$ & $\ldots$ & $\ldots$ & $\ldots$ & $\ldots$ & $\ldots$ & $\ldots$ & $\ldots$ & A \\
\hline JT4 & $\mathrm{BR}$ & $\mathrm{HV}$ & $\ldots$ & $\ldots$ & $\ldots$ & $\ldots$ & $\ldots$ & $\ldots$ & $\ldots$ & $\ldots$ & $\mathrm{E}$ \\
\hline Xcc528 & $\mathrm{BR}$ & $\mathrm{HV}$ & $\mathrm{BR}$ & $\mathrm{BR}, \mathrm{LS}$ & $\mathrm{BR}$ & $\mathrm{BR}$ & $\mathrm{BR}$ & $\mathrm{BR}$ & $\ldots$ & - & $\mathrm{B}$ \\
\hline BR6 & $\mathrm{BR}$ & $\mathrm{V}$ & BR, LS & BR, LS & - & $\mathrm{BR}$ & $\mathrm{BR}$ & $\mathrm{BR}$ & - & - & A \\
\hline BR17 & $\mathrm{BR}$ & V & $\mathrm{BR}, \mathrm{LS}$ & $\mathrm{BR}, \mathrm{LS}$ & - & $\mathrm{BR}$ & $\mathrm{BR}$ & - & - & - & A \\
\hline BR30, BR31 & $\mathrm{BR}$ & $\mathrm{V}$ & BR, LS & BR, LS & BR & $\mathrm{BR}$ & BR & - & - & - & B \\
\hline BR37 & BR & V & BR, LS & BR, LS & - & BR & $\mathrm{BR}$ & BR & $\ldots$ & - & A \\
\hline 3150 & $\mathrm{BR}$ & $\mathrm{V}$ & $\mathrm{BR}$ & $\mathrm{BR}, \mathrm{LS}$ & $\mathrm{BR}$ & $\mathrm{BR}$ & $\mathrm{BR}$ & $\mathrm{BR}$ & $\ldots$ & - & $\mathrm{B}$ \\
\hline BR18 & BR & MV & - & $\mathrm{BR}$ & $\mathrm{BR}$ & BR & $\mathrm{BR}$ & $\mathrm{BR}$ & - & - & B \\
\hline BR19 & $\mathrm{BR}$ & MV & - & $\mathrm{BR}$ & BR & $\mathrm{BR}$ & BR & - & - & - & B \\
\hline BR5, BR9 & $\mathrm{BR}$ & WV & BR, LS & BR, LS & - & $\mathrm{BR}$ & BR & BR & - & - & A \\
\hline $3152^{y}$ & BR & WV & $\mathrm{BR}$ & $\mathrm{BR}$ & $\mathrm{BR}$ & BR & $\mathrm{BR}$ & BR & $\ldots$ & - & A \\
\hline BR1 & - & AV & - & - & - & - & $\mathrm{BR}$ & $\mathrm{BR}$ & - & - & A \\
\hline BR13, BR35 & - & $\mathrm{AV}$ & - & - & - & - & - & - & - & - & A \\
\hline BR15, BR23 & - & $\mathrm{AV}$ & - & - & - & - & - & - & - & - & $\mathrm{E}$ \\
\hline BR20, BR26, BR27, 16937 & - & $\mathrm{AV}$ & - & - & - & - & - & - & - & - & $\mathrm{C}$ \\
\hline \multicolumn{12}{|l|}{ pv. armoraciae } \\
\hline BR11 & SL & $\ldots$ & LS & LS & LS & LS & LS & LS & LS & LS & A \\
\hline BR16, XLS6 & SL & $\ldots$ & LS & LS & LS & LS & LS & LS & LS & LS & $\mathrm{C}$ \\
\hline BR25, BR32 & SL & $\ldots$ & LS & LS & LS & LS & LS & - & LS & LS & A \\
\hline $756,3145,16936^{z}$ & SL & $\ldots$ & LS & LS & LS & LS & LS & LS & $\ldots$ & LS & $\mathrm{C}$ \\
\hline $69-2$ & SL & $\ldots$ & $\ldots$ & $\ldots$ & $\ldots$ & $\ldots$ & $\ldots$ & $\ldots$ & $\ldots$ & $\ldots$ & $\mathrm{D}$ \\
\hline
\end{tabular}

u For each assay, three plants were inoculated per strain and assays were repeated; $(\ldots)=$ not determined

${ }^{\mathrm{v}}$ Excised cotyledon assay on cabbage seedlings (see text) where $\mathrm{SL}=$ stem lesions 4 to 7 days after inoculation, BR $=$ symptoms of black rot 14 days after inoculation. Severity of black rot was assessed using a disease index (DI) of 0 to 9 where $0=$ no symptoms and $9=$ dead plant. Strains were classified as avirulent $(\mathrm{AV})$ for $\mathrm{DI}=0$ to 1 , weakly virulent $(\mathrm{WV})$ for $\mathrm{DI}=1.1$ to 3 , moderately virulent $(\mathrm{MV})$ for $\mathrm{DI}=3.1$ to 6 , virulent $(\mathrm{V})$ for $\mathrm{DI}=6.1$ to 8 , and highly virulent $(\mathrm{HV})$ for $\mathrm{DI}=8.1$ to 9 .

${ }^{\mathrm{w}}$ Symptoms in spray inoculations (see text) were classified as: $(-)=$ no symptoms; black rot $(\mathrm{BR})=$ marginal, V-shaped lesions with darkened veins; and leaf spot $(\mathrm{LS})=$ interveinal lesions bordered by chlorotic halos

${ }^{x}$ Groupings by banding pattern of rep-PCR products using the BOXA1R primer (see Fig. 2).

y Strain was received as pv. armoraciae, however, it is classified here as pv. campestris based on the cotyledon assay.

${ }^{\mathrm{z}}$ Strain was received as $X$. campestris "A", however, it is classified here as pv. armoraciae based on the cotyledon assay. 
bon source utilization produced two groups that contained strains of each pathovar. However, Biolog typing was useful for the identification of strains to the species level. Our results were similar to those of Jones et al. (10) who examined over 600 strains of $X$. campestris and found that Biolog correctly identified $97 \%$ to species, but only $20 \%$ to pathovar.

Although rep-PCR can be a rapid and reliable method to differentiate plant pathogenic bacteria $(12,13)$, this method did not differentiate strains of $X$. campestris pv. campestris and pv. armoraciae in the present study. Fingerprints for strains of the two pathovars were diverse, and the five fingerprint groups (A and C). Similar results were obtained for strains of $X$. campestris pv. campestris from another study that used the ERIC primer (14). Louws et al. identified at least seven disboth pathovars were present within two of

tinct groups for strains from cabbage collected from North and South Carolina (14). Alvarez used RFLP analysis to compare strains of $X$. campestris pv. campestris and pv. armoraciae and found that both pathovars were genetically heterogeneous (1).

In this study, there was no consistent relationship between rep-PCR group, $\mathrm{Bi}$ olog group, original host, virulence, or host range. These results suggest that $X$. campestris may undergo considerable genetic reassortment. Several studies have shown that genetic variation was greater among strains of pathogens with wide host ranges, such as $X$. campestris pv. campestris, $X$. campestris pv. armoraciae, and $P$. syringae pv. syringae, than among pathogens with a more restricted host range, such as $P$. syringae pv. tomato $(1,11,12)$. Our results showed that $X$. campestris pv. armoraciae had a larger host range than previously

\section{$\begin{array}{llllllllllllllllllll}M & 1 & 2 & 3 & 4 & 5 & 6 & 7 & 8 & 9 & 10 & 11 & 12 & 13 & 14 & 15 & 16 & 17 & 18\end{array}$}

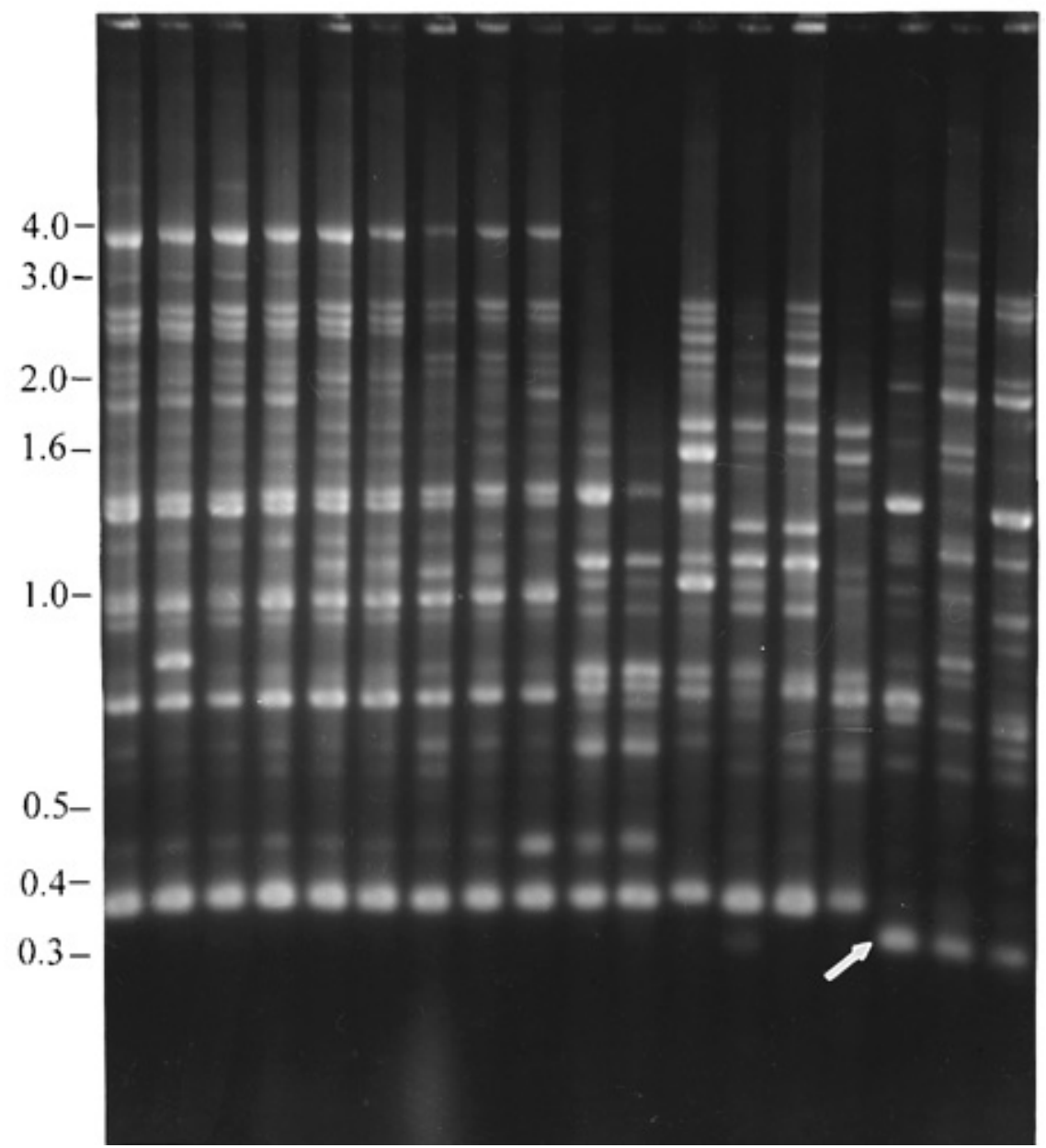

Fig. 2. Repetitive sequence-based polymerase chain reaction (rep-PCR) fingerprint patterns obtained from representative strains of Xanthomonas campestris pv. campestris, X. campestris pv. armoraciae, and nonpathogenic $X$. campestris with the BOXA1R primer. A portion of the PCR product $(8 \mu \mathrm{l})$ was loaded to a $1.5 \%$ agarose gel, and electrophoresis was performed at $70 \mathrm{~V}$ for $5 \mathrm{~h}$ in $1 \mathrm{X}$ TBE buffer. Group A-lane 1, Xcc1205; 2, JT-1; 3, PHW117; 4, BR42; 5, BR21; 6, BR9; 7, BR13; 8, BR32; and 9, 3152. Group B-lane 10, Xcc528; 11, 3150. Group C-lane 12, 16936; 13, 756; and 14, BR16. Group D-lane 15, 69-2; and Group E-lane 16, JT-4; 17, BR15; and 18, BR23. M, DNA molecular size marker (1 kb ladder; Gibco BRL, Gaithersburg, MD); sizes are indicated in kilobase pairs. Arrow indicates common band among strains in Group E. reported $(4,23,30,34)$, including tomato, radish, and horseradish.

More research is needed to determine the relative importance of, and sources of inoculum for, the two pathovars of $X$. campestris in the bacterial disease complex in Oklahoma. In spray inoculations, $X$. campestris pv. armoraciae was a more aggressive leaf spot pathogen than $X$. campestris pv. campestris, and caused leaf spot on a wider range of leafy crucifers. While genetic and phenotypic diversity of strains across fields was high, strains within fields were often similar. For example, strains of $X$. campestris pv. campestris from the cabbage field and from three other fields in eastern Oklahoma had very similar genetic fingerprints and pathogenicity profiles. It is possible that these originated from a single source of inoculum.

\section{ACKNOWLEDGMENTS}

We thank L. Black, D. Cuppels, D. Gabriel, R. Stall, and P. Williams for providing strains; and $\mathrm{J}$. Fletcher and R. Hunger for reviewing the manuscript. Approved for publication by the Director, Oklahoma Agricultural Experiment Station. This research was funded in part by the Oklahoma Agricultural Experiment Station.

\section{LITERATURE CITED}

1. Alvarez, A. M., Benedict, A. A., Mizumoto, C. Y., Hunter, J. E., and Gabriel, D. W. 1994 Serological, pathological, and genetic diversity among strains of Xanthomonas campestris pv. campestris infecting crucifers. Phytopathology 84:1449-1457.

2. Anonymous. 1994. The Importance of Plant Disease Management in US. Production of Leafy Green Vegetables. USDA-National Agric. Pesticide Impact Assessment Program, Report no. 1-CA-94.

3. Black, L. L., and Machmud, M. 1983. Xanthomonas leaf spot of crucifers. Page 126 in: Int. Congr. Plant Pathol., 4th, Melbourne, Australia.

4. Bradbury, J. F. 1986. Guide to Plant Pathogenic Bacteria. CAB, Slough, England.

5. Chang, C. J., Donnaldson, R., Crowley, M., and Pinnow, D. 1991. A new semiselective medium for the isolation of Xanthomonas campestris pv. campestris from crucifer seeds. Phytopathology 81:449-453.

6. Chen, J., Roberts, P. D., and Gabriel, D. W 1994. Effects of a virulence locus from Xanthomonas campestris 528T on pathovar status and ability to elicit blight symptoms on crucifers. Phytopathology 84:1458-1465.

7. Daniels, M. J., Barber, C. E., Turner, P. C. Cleary, W. C., and Sawczyc, M. K. 1984. Isolation of mutants of Xanthomonas campestris pv. campestris showing altered pathogenicity. J. Gen. Microbiol. 130:2447-2455.

8. Fukui, R. A., Arias, R., and Alvarez, R. 1994. Efficacy of four semiselective media for the recovery of Xanthomonas campestris pv. campestris from tropical soils. J. Appl. Bact. 77:534-540.

9. Gitaitis, R. D., Sasser, M. J., Beaver, R. W. McInnes, T. B., and Stall, R. E. 1987. Pectolytic xanthomonads in mixed infection with Pseudomonas syringae pv. syringae, Pseudomonas syringae pv. tomato, and Xanthomonas campestris pv. vesicatoria in tomato and pepper transplants. Phytopathology 77:611-615.

10. Jones, J. B., Chase, A. R., and Harris, G. K. 1993. Evaluation of the Biolog GN microplate system for identification of some plant-pathogenic bacteria. Plant Dis. 77:553-558. 
11. Little, E. L., Bostock, R. M., and Kirkpatrick, B. C. 1998. Genetic characterization of Pseudomonas syringae pv. syringae strains from stone fruits in California. Appl. Environ. Microbiol. 64:3818-3823

12. Louws, F. J., Fulbright, D. W., Stephens, C. T., and de Bruijn, F. J. 1994. Specific genomic fingerprints of phytopathogenic Xanthomonas and Pseudomonas pathovars and strains generated with repetitive sequences and PCR. Appl. Environ. Microbiol. 60:2286-2295.

13. Louws, F. J., Fulbright, D. W., Stephens, C. T., and de Bruijn, F. J. 1995. Differentiation of genomic structure by rep-PCR fingerprinting to rapidly classify Xanthomonas campestris pv. vesicatoria. Phytopathology 85:528536.

14. Louws, F. J., Smith, J. P., and Keinath, A. P. 1998. Xanthomonas campestris pv. campestris lineages in commercial cole-crop fields. (Abstr.) Phytopathology 88:S56.

15. Machmud, M., and Black, L. L. 1985. A Xanthomonas leaf spot of crucifers caused by Xanthomonas campestris pv. armoraciae. Contributions, Central Res. Inst. for Food Crops, Bogor. No. 74:1-13.

16. McCulloch, L. A. 1929. A bacterial leaf spot of horseradish caused by Bacterium campestris var. armoraciae. N. Var. J. Agric. Res. 38:269-287

17. Moffett, M. L., Trimboli, D., and Bonner, I. A. 1976. A bacterial leaf spot disease of several Brassica varieties. Aust. Plant Pathol. Soc. Newsl. 5:30-32.

18. Onsando, J. M. 1992. Black rot of crucifers. Pages 243-252. In: Plant Diseases of International Importance. Vol. II, Diseases of Vegetables and Oil Seed Crops. A. N. Mukhopadhyay and U. S. Singh, eds. Prentice Hall, New Jersey.
19. Poplawsky, A. R., and Chun, W. 1995. Strains of Xanthomonas campestris pv. campestris with atypical pigmentation isolated from commercial crucifer seeds. Plant Dis. 79:1021-1024.

20. Preston, D. A. 1945. Host Index of Oklahoma Plant Diseases. Okla. Agric. \& Mech. College. Agric. Exp. Sta., Tech. Bull. No. T-21.

21. Randhawa, P. S., and Schaad, N. W. 1984. Selective isolation of Xanthomonas campestris pv. campestris. Phytopathology 74:268272.

22. Rohlf, F. J. 1992. NTSYS-PC: Numerical Taxonomy and Multivariate Analysis System. Version 1.70, Exeter Software, Setauket, New York.

23. Sahin, F., and Miller, S. A. 1997. A new pathotype of Xanthomonas campestris pv. armoraciae that causes bacterial leaf spot of radish. (Abstr.) Plant Dis. 81:1334.

24. Sambrook, J., Fritsch, E. F., and Maniatis, T. 1989. Molecular Cloning: A laboratory manual. 2nd Ed. Cold Spring Harbor Laboratory Press, Cold Spring Harbor, New York.

25. Schaad, N. W., ed. 1988. Laboratory Guide for Identification of Plant Pathogenic Bacteria. 2nd Ed. American Phytopathological Society, St. Paul, MN.

26. Shaw, J. J., and Kado, C. I. 1987. Whole plant wound inoculation for consistent reproduction of black rot of crucifers. Phytopathology 78:981-986.

27. Shen, F. J., and Chen, W. L. 1990. Preliminary study on cruciferous black rot in Zhejiang. Acta Agric. Univ. Zhejiang. 16 (Suppl.):252257.

28. Sherf, A. F., and MacNab, A. A. 1986. Vegetable Diseases and Their Control. 2nd Ed. John Wiley and Sons, New York.

29. Simpson, R. B., and Johnson, L. J. 1990. Arabidopsis thaliana as a host for Xantho- monas campestris pv. campestris. Mol. Plant Microbe Interact. 3:233-237.

30. Tamura, K., Takikawa, Y., Tsuyumu, S., and Goto, M. 1994. Bacterial spot of crucifers caused by Xanthomonas campestris pv. raphani. Ann. Phytopathol. Soc. Jpn. 60:281287.

31. Tsuji, J., and Somerville, S. G. 1992. First report of natural infection of Arabidopsis thaliana by Xanthomonas campestris pv. campestris. (Abstr.) Plant Dis. 76:539.

32. Vauterin, L., Hoste, B., Kersters, K., and Swings, J. 1995. Reclassification of Xanthomonas. Int. J. Syst. Bacteriol. 45:472-489.

33. Vauterin, L., Yang, P., and Swings, J. 1996. Utilization of fatty acid methyl esters for the differentiation of new Xanthomonas species. Int. J. Syst. Bacteriol. 46:298-304.

34. White, H. E. 1930. Bacterial spot of radish and turnip. Phytopathology 20:653-662.

35. Williams, P. H. 1980. Black rot: a continuing threat to world crucifers. Plant Dis. 64:736742.

36. Yuen, G. Y. K., and Alvarez, A. M. 1985. Aberrant symptoms on cabbage caused by strains of Xanthomonas campestris. (Abstr.) Phytopathology 75:1382.

37. Zeng, Z. M., and Huang, Q. Z. 1994. Identification of the pathogenic bacteria of a new tobacco disease - black rot. J. South China Agric. Univ. 15:46-49.

38. Zhao, Y. F., Damicone, J. P., Demezas, D. H. Rangaswamy, V., and Bender, C. L. 1998. Characterization of bacterial leaf spots of leafy green vegetables in Oklahoma. (Abstr.) Phytopathology 88:S104.

39. Zhao, Y., Damicone, J. P., Demezas, D. H., Rangaswamy, V., and Bender, C. L. 2000 Bacterial leaf spot of leafy crucifers in Oklahoma caused by Pseudomonas syringae pv. maculicola. Plant Dis. 84:1015-1020. 